\title{
Introduction: an interdisciplinary inquiry into the relationship between fresh water, the rule of law and international relations
}

\author{
Mara Tignino and Christian Bréthaut
}

Only a small quantity of fresh water - around 2.53 per cent of total water availability - can be used for human needs (be they drinking water, irrigation, industrial purposes, etc.). Moreover, a significant portion of this fresh water is locked in ice or relates to groundwater resources. Some of those resources, those that have insufficient sources of recharge, can become non-renewable resources and risk being exhausted. As a scarce resource, water therefore has a high potential for triggering and crystalizing conflicts among users. This feature will become increasingly important as water scarcity is intensified by rapid environmental changes such as climate change and accompanied by uncertain impacts. ${ }^{1}$

Since the 1990s, studies on the relationship between fresh water, the rule of law and international relations have developed in different directions. On the one hand, the number of institutional and legal frameworks - intended in their broad meaning as the 'rule of law' - has been significantly expanded. Fresh water law today includes a number of agreements at the universal, regional and basin levels. ${ }^{2}$ On the other hand, social sciences provide numerous theoretical frameworks through which to examine the interactions over shared

\footnotetext{
1 In 2014, the Intergovernmental Panel on Climate Change (IPCC) emphasized: 'In many regions, changing precipitation or melting snow and ice are altering hydrological systems, affecting water resources in terms of quantity and quality. Glaciers continue to shrink almost worldwide due to climate change, affecting runoff and water resources downstream. Climate change is causing permafrost warming and thawing in high-latitude regions and in high-elevation regions'. Climate Change 2014: Impacts, Adaptation, and Vulnerability, Summary for Policymakers, 2014. See M Stoffel, ZW Kundzewicz and M Beniston, 'Fresh water resources and climate change', infra Chapter 11.

2 Of particular relevance is the entry into force of the 1997 UN Convention on the Law of the Non-Navigational Uses of International Watercourses (hereinafter the UN Watercourses Convention) and the opening of the 1992 Convention on the Protection and Uses of Transboundary Watercourses and International Lakes (hereinafter the Water Convention) to all UN Member States. See L Boisson de Chazournes, Fresh Water in International Law (OUP 2013).
} 
water resources and to analyse the reasons underlying conflicts and cooperation between States and/or non-State actors in a multi-level perspective. ${ }^{3}$

As illustrated in this Handbook, the complexity of problems and the diversity of concerned actors call for numerous types of analysis on the interplay between fresh water law and international relations. In this regard, multi and interdisciplinary approaches play a key role in attempting to grasp complexity and to intelligently informing policy measures. Research draws from, and spans, several disciplines, including - among others - international law, political science, geography, hydrogeology and ethics. We believe that dialogue and exchange between legal, social and environmental science scholars can contribute to providing the necessary knowledge and tools to improve the management and protection of water resources.

\section{STRUCTURE OF THE HANDBOOK}

This Handbook brings together scholars from legal, social and environmental sciences to examine water management and protection. It takes into account the most recent developments in these areas of research and addresses six main questions: (1) What are the characteristics of water resource management and protection at the international and domestic levels and how have they evolved? (2) How has fresh water law developed to prevent and settle water disputes over the last decades? (3) What are the challenges related to the implementation of regulatory frameworks over water from the local to the global level? (4) What are the issues at stake in the implementation of the human right to water and sanitation? (5) How has the law of transboundary aquifers developed and been applied? and (6) What is the interplay between fresh water and the social and environmental sciences?

With the objective of addressing these questions, this Handbook includes four parts: (1) the qualifications of fresh water in international law; (2) the sources of international principles and norms, being customary or treaty law, dealing with the management and the protection of fresh water resources; (3) the features of specific regimes on fresh water, including the human right to water and sanitation and the law of transboundary aquifers; and (4) the role of social and environmental sciences in shaping legal and institutional frameworks on shared water resources.

3 See L Maertens and G Pflieger, 'Studying international water conflict', infra Chapter 15. 


\section{THE QUALIFICATION OF FRESH WATER IN INTERNATIONAL LAW}

Chapter 1 entails an examination of the concepts of 'common concern' and 'common heritage' in fresh water law. These concepts recognize the common interests shared by States in the conservation and sustainable use of specific areas and resources. Both concepts induce an idea of cooperation between States and intergenerational solidarity. It is from this perspective that States - not only the riparian States to an international watercourse - share a vital interest in the protection of water resources. Applying a common heritage regime to fresh water resources challenges the principle of State sovereignty. There is no instrument qualifying explicitly fresh water as a common concern of humankind or common heritage. However, fresh water management transcends territoriality and may pose a challenge calling for global action. Even if an emerging international consensus on fresh water availability can be identified as constituting a common concern, applying a common heritage regime at the global scale in the same way as in the United Nations Convention on the Law of the Sea (UNCLOS) is less realistic. A common heritage regime would allow hydrologically disadvantaged States a legal interest in the protection of the global hydrologic cycle. ${ }^{4}$

Chapter 2 focuses on the case of privatization of water services. The pricing of water and market mechanisms have been presented as ways to reflect the economic value of water in its different uses to prevent wasteful and environmentally harmful uses of water. Studying the economic value of water underlines the need to reconcile economic and non-economic considerations in water management. Through an analysis of arbitration cases related to water concessions, it is argued that a balance should be struck between the protection of investments and the right of the State to preserve a scarce natural resource such as water as a public policy matter. ${ }^{5}$

Chapter 3 deals with the environmental management of water resources. Environmental concerns are of growing importance in the law of international water$\operatorname{courses}^{6}$ and, as empirical cases illustrate, these concerns must be addressed prior to permitting economic uses of the watercourse concerned. ${ }^{7}$ The principle of environmental protection of water resources cuts across different dimensions

\footnotetext{
4 S Kpenou, 'Fresh water as common heritage and a common concern of mankind', infra Chapter 1.

5 B Zerhdoud, 'The economic management of water resources: the case of the investorState disputes in the context of concession contracts', infra Chapter 2.

6 Gabčikovo-Nagymaros (Hungary/Slovakia) (Judgment) [1997] ICJ Rep 7; Pulp Mills on the River Uruguay (Argentina v Uruguay) (Judgment) [2010] ICJ Rep 14. Rep 14.

Pulp Mills on the River Uruguay (Argentina v Uruguay) (Judgment) [2010] ICJ
} 
of fresh water law, including substantive and procedural norms. Substantive principles include reasonable and equitable use of transboundary watercourses and the obligation not to cause significant harm. The duties of cooperation and the notification of planned projects are illustrations of procedural norms. ${ }^{8}$

Chapter 4 examines the management of water in urban contexts. While 54 per cent of the population worldwide live in cities, forecasts estimate that this figure will be 66 per cent by $2050 .{ }^{9}$ The analysis of case studies in the Latin American region illustrates many of the challenges related to urban water management. Indeed, Latin America is the most urbanized continent. This region has faced several waves of water conflict, from the context of the privatization of water services in the 1990s to the conflicts emerging from the intensification of extractive practices implemented by States. These conflicts are studied taking into account the interaction between public, private and community actors. The human right to water is also examined in the context of urban water management to show its impact on the regulation of water uses at the national and local levels. ${ }^{10}$

Chapter 5 studies the relationship between water and international peace and security in the practice of the UN Security Council. Water, as an indispensable resource for human survival and socio-economic development, has a significant value in national and international policy. At the international level, water concerns have entered in the field of collective security, from conflict prevention to peacebuilding. The thematic discussions held in the Security Council in 2016 and $2017^{11}$ show that legal mechanisms of cooperation must be developed on the sharing and protection of water resources. Solid international legal frameworks are necessary to prevent sources and accelerators of conflicts. The development and strengthening of the rule of law is deemed pivotal to avert the risk of conflicts. ${ }^{12}$

8 MM Mbengue and N Odili, 'The environmental management of water resources: what impact on the characterization of fresh water in international law?' infra Chapter 3.

9 United Nations, Managing Water under Uncertainty and Risk (World Water Development Report 4, vol 1, 2012).

10 E Dupuits, 'Urban water management: from the human rights framework to political challenges in Latin America' infra Chapter 4.

11 See the thematic discussions on water, peace and security, UNSC Meeting Record (22 November 2016) UN Doc S/PV/7818; and on preventive diplomacy and transboundary waters, UNSC Meeting Record (6 June 2017) UN Doc S/PV/7959.

12 M Tignino, 'Water in the practice of the United Nations Security Council: trends and new perspectives' infra Chapter 5 . 


\section{SOURCES OF INTERNATIONAL LAW IN THE MANAGEMENT AND PROTECTION OF FRESH WATER RESOURCES}

The journey of analysing of the interaction between fresh water law and international relations continues in Section 2 of the Handbook. The various contributions investigate the management and protection of water resources at the transboundary and national levels. Chapter 6 scrutinizes the content and extent of the rules of customary international law that have developed, and are continuing to develop, concerning the non-navigational uses of international watercourses. In identifying these rules, it is necessary the examination of the International Court of Justice's jurisprudence and the relevant work of the International Law Commission (ILC). This practice may be considered the best evidence of customary international law. There is broad agreement on two customary obligations governing the management and protection of shared water resources: the equitable and reasonable utilization and the prevention of significant harm. Also important are the general obligation to cooperate, and the prior notification of planned measures. This body of customary law, which is largely reflected in the Convention on the Law of the Non-Navigation Uses of International Watercourses (UN Watercourses Convention), continues to grow and to be refined through International Court of Justice's decisions and arbitral tribunals' awards. ${ }^{13}$ In the absence of a universally-applicable treaty containing the fundamental obligations relating to international watercourses, rules of customary international law are of assistance to States in their relations with co-riparian States and in their efforts to protect and manage international watercourses. $^{14}$

Chapter 7 argues that the multifaceted aspects of fresh water law point to the need for a multilevel legal system. However, there exists a wide gap between global needs and local realities. In this sense, regional organizations and regional law may the ideal point of mediation between these different levels of governance. The study of the practice of regional organizations such as the European Union and Mercosur underlines the mutual learning between these two organizations. Stronger synergies within the rule of law and other fields of scientific knowledge should also be promoted to achieve international goals.

13 See, in particular, the Indus Waters Kishenganga Arbitration (Pakistan v India), PCA Case No 2011-01 <https://pca-cpa.org/en/cases/20/> accessed 22 August 2018 and the Iron Rhine Arbitration (Belgium v Netherlands), PCA Case No 2003-02<https:// pca-cpa.org/en/cases/1/> accessed 22 August 2018.

14 SC McCaffrey, 'The customary law of international watercourses' infra Chapter 6. 
Interdisciplinary studies may have a positive impact on the development of law and facilitate its continuous adjustment to complex challenges. ${ }^{15}$

Chapters 8 and 9 note that the practice of international tribunals and courts consolidates customary principles and rules of fresh water law. Moreover, judicial and diplomatic means exist to assist States in the resolution of water conflicts. Dispute settlement provisions are contained in the 1992 Convention on the Protection and Use of Transboundary Watercourses and International Lakes adopted under the aegis of the United Nations Economic Commission for Europe (UNECE Water Convention) and the 1997 UN Watercourses Convention. ${ }^{16}$ Contrary to the case of the law of the sea, for example, in fresh water law there are no generally agreed upon compulsory methods producing final and binding solutions. In certain treaties or cases, however, the litigant States have agreed or agree on jurisdictional methods of settlement, through the application of conventional and customary rules of international law. ${ }^{17}$

Chapter 9 explores conflict related to the development of hydropower installations. The production of hydroelectricity is becoming increasingly attractive to States. However, hydroelectric projects involve enormous investment and have significant impacts: social, economic, environmental and others. When hydroelectric power generation projects are constructed and operated on international watercourses, disputes between riparians often arise. International courts and tribunals have had to consider the rights of use of riparian states on transboundary rivers in the context of disputes concerning hydroelectricity projects. They have dealt with the antagonism between, on the one hand, the permanence and need for stability for the construction and operation of hydroelectric projects and, on the other hand, the development of international law and the changing scientific and environmental conditions and values concerning the transboundary rivers. ${ }^{18}$

\section{SPECIFIC REGIMES OF FRESH WATER RESOURCES}

Section 3 continues with the analysis, focussing on specific fresh water governance regimes. Chapter 12 gives an in-depth analysis of the right to water. Several international documents have recognized this right. These include the

15 A Correia Lima Macedo Franca, "Glocal" water management and regional organizations: multi-level law and transjuridicty' infra Chapter 7.

16 A Tanzi, 'Diplomacy, responsibility and accountability in transboundary water disputes' infra Chapter 8.

17 L Caflisch, 'Settlement of disputes concerning international watercourses' infra Chapter 10.

${ }_{18}$ D Azaria, 'Fresh water and energy in international courts and tribunals: hydroelectricity installations on trasnboundary rivers' infra Chapter 9. 
General Comment No.15 adopted by the UN Committee on Economic, Social and Cultural Rights in 2002, ${ }^{19}$ the Draft Guidelines for the Realization of the Right to Water and Sanitation adopted by the Sub-Commission on the Promotion and Protection of Human Rights in $2005^{20}$ and the resolutions recognizing the human rights to water and sanitation adopted by the UN General Assembly and the Human Rights Council in 2010. ${ }^{21}$ Since then, the Human Rights Council has affirmed the right to water in several resolutions..$^{22}$ Although each of these documents has a particular nature, has been adopted by distinct international bodies, and employs different language, all of them highlight States' acknowledgement that the issue of access to drinking water and basic sanitation services should be understood as an established obligation under international law. ${ }^{23}$

Another specific regime examined in this Handbook concerns the contours of the law applicable to transboundary aquifers. ${ }^{24}$ Given that groundwater represents 97 per cent of available water, these norms are of particular relevance. Both the 1997 UN Watercourses Convention and the 1992 Water Convention cover these resources, with the scope of the latter being wider than the former. ${ }^{25}$ In 2008, the International Law Commission (ILC) adopted the Draft Articles on the Law of Transboundary Aquifers. ${ }^{26}$ The UN General Assembly has since considered the Draft Articles in 2008, 2011, 2013, and 2016 ${ }^{27}$ and commended the Draft Articles to States 'as guidance for the adoption of regional agreements or arrangements for the proper management of transboundary aquifers'. The

19 UN Committee on Economic, Social and Cultural Rights 'General Comment No 15 on the Right to Water (Articles 11 and 12 of the International Covenant on Economic, Social and Cultural Rights)' (2002) UN Doc E/C.12/2002/11 <http://tbinternet.ohchr. org/_layouts/treatybodyexternal/Download.aspx?symbolno=E\%2fC.12\%2f2002\%2f11 \&Lang=en> accessed 18 April 2017.

20 Sub-Commission on the Promotion and Protection of Human Rights 'Draft Guidelines for the Realization of the Right to Water and Sanitation' (11 July 2005) E/ CN.4/Sub.2/2005/25.

21 UNGA 'The Human Right to Water and Sanitation' (28 July 2010) UN Doc A/ RES/64/292; 'Human Rights and Access to Safe Drinking Water and Sanitation' (30 September 2010) HRC/C/15/L.14.

${ }_{22}$ See, for example, HRC, 'The Human Right to Safe Drinking Water and Sanitation' (5 October 2016) HRC/RES/33/10; HRC, 'The Human Right to Safe Drinking Water and Sanitation (7 October 2013) HRC/RES/24/18.

23 Salman MA Salman, 'The human right to water and sanitation: challenges and opportunities' infra Chapter 12.

${ }_{24}$ R Martin-Nagle and S Hawkins, 'Transboundary aquifers' infra Chapter 13.

25 See Article 1.1 of the 1992 Water Convention, and Article 2.2(a) of the UN Watercourses Convention.

26 ILC, 'Draft Articles on the Law of Transboundary Aquifers' (29 May 2008) UN DOC A/CN.4/L.724.

27 See, for example, UNGA, 'The Law of Transboundary Aquifers' (16 December 2013) UN DOC A/RES/68/118. 
Model Provisions on Groundwater Resources, adopted within the framework of the 1992 UNECE Water Convention in 2012, reflect the language of the ILC Draft Articles. ${ }^{28}$ The compatibility of the model provisions with the ILC Draft Articles reinforces the law of groundwater resources.

Chapter 14 examines a field of fresh water law that should still be strengthened concerning norms on liability and responsibility. This need may be due in part to the fact that primary rules of fresh water law are somewhat normatively indeterminate, while secondary rules of international law on State responsibility and liability, long under development by the ILC, ${ }^{29}$ may pose difficulties to the definition of environmental damage to transboundary water resources. In response, States may seek to employ other means to resolve transboundary water disputes, including negotiation, crafting specific institutional mechanisms, ad hoc resolution arrangements or referral to compliance mechanisms associated with international water resource agreements or multilateral environmental agreements. ${ }^{30}$

\section{BEYOND INTERNATIONAL LAW: THE INTERPLAY BETWEEN FRESH WATER AND SOCIAL AND ENVIRONMENTAL SCIENCES}

Part 4 of this Handbook examines the relationship between water and specific areas of environmental and social sciences - the interdisciplinary stances that structure this volume. It also provides the reader with an assessment of policy instruments that may affect water resources management.

Chapter 15 explains the need for an interdisciplinary approach through the analysis of cooperation and conflict mechanisms over fresh water. ${ }^{31}$ The study of international water conflicts requires identifying the multiple actors involved, their intentions, the different scales of their intervention and the various dimensions of these tensions (economic, environmental, political and social) over time. For example, linking water to trade or economic benefits - that can also be provided through a third party with side payments encouraging 'induced

28 United Nations Economic Commission for Europe (UNECE), Model Provisions on Groundwater Resources, 2012 <www.unece.org/fileadmin/DAM/env/water/ publications/WAT_model_provisions/ece_mp.wat_40_eng.pdf $>$ accessed 17 May 2018.

${ }_{29}$ See J Crawford (ed), The International Law Commission's Articles on State Responsibility (CUP 2002).

30 See O McIntyre, 'Responsibility and liability in international law for damage to transboundary fresh water resources' infra Chapter 14; T Bolognesi and C Bréthaut, 'An institutionalist perspective on the use of international water law: crafting institutions in a multi-level setting' infra Chapter 17.

${ }^{31}$ L Maertens and G Pflieger, 'Studying international water conflict' infra Chapter 15. 
cooperation ${ }^{\prime 32}$ - could facilitate cooperation over fresh water. In return, water cooperation, as a platform between low and high politics, can help cooperation in other aspects of foreign policy. ${ }^{33}$ Under specific conditions, institutions can foster cooperation such as in the case of shared rivers. ${ }^{34}$

Chapter 16 assesses the notion of benefit sharing in international water law. Water generates a multitude of benefits. It provides access to water for drinking and direct human consumption, it grows food, produces electricity and provides transport routes and habitat, among other benefits. The concept of benefit sharing applied by countries to transboundary water management may increase the benefits they can derive from shared water resources. Case studies and international practice show the use of legal mechanisms and rules to increase and share benefits between riparian States that can be derived from cross-border rivers, lakes and aquifers. ${ }^{35}$

Chapter 17 investigates the diversity of legal mechanisms used to increase cooperation over shared water resources. Institutional frameworks play a crucial role in ensuring access to information and participation at the local level. The institutional environment and institutional crafting at the transboundary level contributes to supporting the rule of law and making coordination credible. The general character of law allows it to cope with a great diversity of situations, and ensures the necessary room for stakeholders to manoeuvre and to craft relevant institutions at the transboundary level. ${ }^{36}$

In addition to political science, hydrogeology, geography and ethics may provide tools for interpreting and applying fresh water law. Chapters 18, 19 and 20 study these areas of research. In particular, Chapter 18 argues that hydrogeology provides the foundation for developing management, policy and adequate governance practices for groundwater. Hydrogeological sciences offer valuable information on the status of groundwater systems and their evolution as a result of pumping and other human pressures. Hydrogeological sciences also support the exchange of data and information needed for designing and putting in place the most appropriate model of governance for a specific aquifer.

\footnotetext{
32 E Weinthal, State Making and Environmental Cooperation: Linking Domestic and International Politics in Central Asia (MIT Press 2002) 38.

33 D Phillips, M Daoudy, SC McCaffrey, J Öjendal and AR Turton, Trans-boundary Water Cooperation as a Tool for Conflict Prevention and for Broader Benefit-sharing: Prepared for the Ministry for Foreign Affairs, Sweden (EGDI Secretariat, Swedish Ministry for Foreign Affairs 2006).

34 R Berardo and A Gerlak, 'Conflict and Cooperation Along International Rivers: Crafting a Model of Institutional Effectiveness' (2012) 12 Glob Env Politics 101-20.

35 L Boisson de Chazournes and C Leb, 'Benefit sharing in international water law: a multi-disciplinary undertaking' infra Chapter 16.

${ }^{36} \mathrm{~T}$ Bolognesi and $\mathrm{C}$ Bréthaut, 'An institutionalist perspective on the use of international water law: crafting institutions in a multi-level setting' infra Chapter 17.
} 
The transboundary dimension of groundwater resources creates an additional complicating factor in the design of legal mechanisms. In this context, the key to successful management of water resources systems is smooth cooperation between the neighbouring countries involved. ${ }^{37}$

Chapter 19 includes an analysis of the role of geography in fresh water management. In this context, the main contributions have been in the field of political geography (water conflict analyses) and spatial implications of Integrated Water Resource Management (IWRM). Recent developments of integrated approaches for water management include measuring anthropogenic impacts on the water cycle, methods for evaluating water stress, and the water footprint concept and approach. ${ }^{38}$

The Handbook concludes with a chapter on water ethics. This is an emerging field in the study of water management and protection. Every creed of the world is more and more eager to understand the various issues involving water management, and they are joining forces to express their concerns that fresh water must be considered a human right, not an economic good. Ethics and water justice should jointly be considered to ensure sustainable uses of water resources and to guarantee the priority to human consumption. ${ }^{39}$

In conclusion, the convergence of various disciplines in the social and environmental sciences contributes to improving knowledge on, and protection of, fresh water resources. This interplay also creates challenges that must be addressed, such as the risk of diverse and potentially conflicting interpretations. This Handbook points out the added value of mobilizing multiple analytical and theoretical viewpoints to grasp water-related challenges and complexity. It also shows that the use of specific terms and notions employed by the various authors does not impede working towards a common objective: providing solid and sound responses to the multiple aspects of water management.

37 A Rivera, A Dumont and A Aureli, 'The role of hydrogeology in fresh water management' infra Chapter 18.

38 M Milano and E Reynard, 'The role of geography in fresh water management' infra Chapter 19.

39 E Fiechter-Widemann, 'The role of ethics in fresh water management: linking the ethic of conviction and the ethic of responsibility' infra Chapter 20. 